\title{
Cash Balance Pension Plan Conversions: An Analysis Of Motivations And Pension Costs
}

\author{
Julia D'Souza, Ph.D., Cornell University, USA \\ John Jacob, Ph.D., (Deceased), University of Colorado at Boulder, USA \\ Barbara Lougee, Ph.D., University of San Diego, USA
}

\begin{abstract}
In recent years, many corporations have replaced their traditional defined benefit (DB) pension plans with "cash balance" (CB) plans, which share many of the characteristics of defined contribution plans. This study provides empirical evidence on the characteristics of CB converters and the behavior of pension costs and obligations pre- and post-conversion. We find that $C B$ converters are larger than firms that retain traditional $D B$ plans as well as those that terminate $D B$ plans. They are less profitable than the former, but more profitable than the latter. $C B$ conversions are not associated with proxies for greater labor mobility (e.g., firm-specific employee turnover rate). They are associated with a workforce that is closer to retirement, on average, lending credence to the breach of implicit contract rather than the labor market hypothesis as a motivator of $C B$ conversions. Consistent with this intuition, we document that $C B$ converters recognize a reduction of unrecognized prior service costs in the year of conversion, consistent with a negative plan amendment. Unlike pre-conversion, pension costs and obligations are significantly lower for $C B$ firms post-conversion than for a matched sample of firms retaining traditional DB plans. $C B$ conversions are more popular than DB plan terminations among firms with overfunded pension plans in periods when expected return on plan assets is likely to be high, with a consequent positive effect on reported income.
\end{abstract}

Keywords: Cash Balance Plans; Pension Plans; Pension Conversions; Postretirement Benefits; SFAS 87

\section{INTRODUCTION}

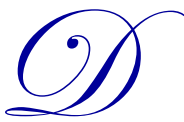

uring the last thirty years, there has been a transformation of the private pension system, with employers offering fewer defined benefit plans. ${ }^{1}$ In one of the most significant developments, many corporations have replaced their traditional defined benefit (henceforth DB) pension plans with cash balance (henceforth CB) plans. Although CB plans are technically DB plans, they share many of the characteristics of defined contribution (henceforth DC) plans. Conversions of DB plans to CB plans have generated extensive coverage in the financial press and have also been the subject of congressional hearings. Critics allege that CB plan conversions are attempts by employers to renege on benefits implicitly promised to their employees and that such conversions are particularly harmful to older employees with longer tenures. Proponents of CB plans assert that, because the accrued benefits are more portable, such plans are better suited to the present labor market where employees change employers frequently.

\footnotetext{
${ }^{1}$ According to the Department of Labor, between 1975 and 2009, the number of defined benefit plans decreased 54\% (from 103,346 to 47,137 ) and the number of participants in defined benefit plans increased $27 \%$ (from 33.0 million to 41.8 million). The March 2012 National Compensation Survey documents that in $201259 \%$ of private industry workers have access to a defined contribution plan and only $19 \%$ of private industry workers have access to a defined benefit plan (down from $32 \%$ in 1996-1997).
} 
The breach of implicit contract controversy is not new: debate on this issue gained prominence during the 1980s, when DB plan terminations were widespread. The preponderance of academic studies find that plan terminations were attempts by financially distressed firms to access excess plan assets, several studies documenting wealth transfers from employees to shareholders. However, whether $\mathrm{CB}$ conversions also tap into workers' pension bond with the firm is not clear. Employers have argued strongly that $\mathrm{CB}$ conversions are a response to the changing needs of a more mobile workforce and that, overall, they are beneficial to workers.

Few studies to date have attempted to distinguish between the competing theories for CB conversions, and these studies have been characterized by relatively small sample sizes and mixed results. To investigate these issues in greater depth, we use a comprehensive sample of CB converters and both plan-level data from Department of Labor (DOL) filings and firm-level data from financial statements. We compare the characteristics of CB converters to two different control samples: the first includes firms that retain their traditional DB plans, and the second consists of firms that terminate or freeze their traditional DB plans. Overall, our results indicate that CB firms are less profitable than firms that retain their DB plans but more profitable than DB plan terminators. They do not have greater employee turnover or industry unemployment rates than firms that retain their traditional DB plans. They do have workforces that are closer to retirement, lending credence to the breach of implicit contract hypothesis rather than the labor market hypothesis. Reinforcing this conclusion is the fact that CB converters, on average, recognize reductions in unrecognized prior service costs in the year of conversion, consistent with a negative plan amendment. Moreover, we find that, in contrast to pre-conversion years, both the pension obligation and pension service costs are, post-conversion, significantly lower for CB firms than for matched traditional DB firms. Overall, results are consistent with $\mathrm{CB}$ conversions being part of a strategy to reduce costs and improve reported profitability.

An analysis of the number of $\mathrm{CB}$ conversions by year reveals an association between the increased popularity of $\mathrm{CB}$ conversions over $\mathrm{DB}$ plan terminations and financial reporting considerations as well as the increase in the excise taxes imposed on reversions of excess pension plan assets in 1990. We document that the largest yearly number of CB conversions prior to the stock market boom of the mid-nineties occurred in 1989, prior to the largest tax increase on plan asset reversions, but immediately following the effective date of SFAS 87, indicating a possible link between the the new pension accounting rules and the increased popularity of CB conversions. Specifically, the expected return on plan assets can substantially reduce the pension expense of firms with overfunded DB plans. Firms that terminate their DB plans lose this financial reporting benefit. Consistent with this argument, we note that the number of CB conversions peaked in the late 1990s, coinciding with the boom in the capital markets. Further, we document a high correlation (0.93) between the number of $\mathrm{CB}$ conversions during a year and the year-end level of the S\&P 500 index, supporting the argument that financial reporting considerations might have influenced the relative attractiveness of the CB conversion option.

We believe our study is the most comprehensive empirical examination of CB conversions to date and makes a significant contribution to the emerging literature on hybrid pension plans. We examine, for the first time, the behavior of the pension obligation and service costs after $\mathrm{CB}$ conversions and provide evidence that conversions succeed in controlling pension costs. By documenting that empirical evidence is more consistent with the breach of implicit contract than the labor market hypothesis, we shed light on the controversy surrounding CB conversions. We find an association between the incidence of $\mathrm{CB}$ conversions and the measurement of pension expense under SFAS 87, linking the pension and financial reporting literatures. Our findings are likely to be of interest to employees, retirees and firms affected by this pension innovation and to policy makers, including Congress and the Financial Accounting Standards Board.

\section{INSTITUTIONAL BACKGROUND AND PRIOR RESEARCH}

Pension plans sponsored by U.S. employers can generally be characterized as either DB or DC plans. Traditional DB plans entitle participants to an annuity of pension benefits upon retirement that is usually a function of salary during their final years of employment (generally their average salary in the last three to five years) and 
their years of service with the employer. ${ }^{2}$ Employees in traditional DB plans earn the major portion of their benefits in the latter part (often the last ten years) of their careers. ${ }^{3}$ Employers generally fund retirement benefits by making contributions that are tax deductible, subject to limits, to trusts specifically formed to pay pensions to eligible retirees. An important aspect of DB pension plans is that the employer bears the risk of the pension plans' investments' performance. ${ }^{4}$

In a DC plan, the employee often has a choice of whether to participate in the plan and how much to contribute to his/her retirement savings account. The employer generally matches some proportion of the employee's contribution. Both the employee's and the employer's contribution are usually invested in the capital markets and the employee often has a choice of investment options. Upon retirement, the employee is entitled to the accumulation in his/her account. The employee earns benefits earlier in his/her career, but bears the risk of the investment performance of assets in his/her retirement account. If an employee separates from the firm prior to retirement, he/she can roll over the vested portion of his/her account balance to another retirement plan. In the past, large employers tended to sponsor DB plans. DC plans have become more popular in the last couple of decades with many employers initiating or expanding such plans, claiming that they are better suited to the current environment of greater employee mobility. ${ }^{5}$

Under a CB plan, employees are assigned nominal accounts. These account balances are increased by pay credits (for instance, $3 \%$ of annual pay) and interest credits based on the account balance. The interest rate used to compute interest credits is often based on the yield on Treasury bonds such as the 30-year or the one-year Treasury bond, although plan assets are not generally invested in these bonds. The interest credits are therefore independent of the performance of pension plan assets. One of the potential benefits of CB plans to firms is the interest arbitrage they can achieve by investing plan assets in higher yielding securities while crediting plan participants account balances at lower Treasury bond rates. In a CB plan, the sum of the employees' account balances does not generally equal the total assets of the pension plan, and the interest credits do not generally correspond to the actual investment earnings of the plan. At retirement, an employee covered by a CB pension plan is entitled to the balance in his/her nominal account, either as a lump sum or an annuity.

CB plans were first developed and promoted by the benefits and actuarial firm Kwasha Lipton (now part of PriceWaterhouseCoopers) and later by larger benefits consultant firms. ${ }^{6}$ Bank of America, one of the first adopters in 1985, claimed that the conversion resulted in savings of $\$ 75$ million in the first year. ${ }^{7}$ The trickle of adoptions that began in the late eighties and early nineties became a flood in the mid and late nineties. The Government Accountability Office estimates that approximately 19\% of the Fortune 1,000 firms had adopted CB plans by 1999, and we were able to identify over 300 adoptions in our sample. While the early adoptions in the 1980s did not receive much attention, some of the adoptions in the late nineties were controversial and resulted in prolonged legal battles. ${ }^{8}$ Conversions to CB plans were the focus of Congressional hearings in 1999 and again in 2003. Based on concerns about age discrimination, the IRS placed a moratorium on CB conversions in 1999; it ended the moratorium in December of 2006. Finally, the Pension Protection Act (PPA) of 2006 clarified the legal status of cash balance pensions and provided safe harbor for cash balance plans as of June 30, 2005. In 2010, the Treasury released new rules that elucidated how to manage cash balance plans.

\footnotetext{
${ }^{2}$ For instance a DB plan may promise annual pension benefits of 1.25 percent of the average of salary during the final three years of employment for every year of service. An employee with 20 years of service would therefore receive an annual pension after retirement of $25 \%$ of the average salary in the last three years prior to retirement.

${ }^{3}$ This effect is even more pronounced in companies that offer subsidized early retirement benefits.

${ }_{5}^{4}$ DB plans are generally covered by guarantees from the Pension Benefit Guaranty Corporation.

${ }^{5}$ The Department of Labor documents that between 1975 and 2009, the number of DC plans increased 218\% (from 207,748 to 659,530 ) and the number of participants in DC plans increased 660\% (from 11.5 million to 87.5 million).

${ }^{6}$ See article by Ellen Schultz, "Pension paternity: How a single sentence by IRS paved the way to cash balance plans," in the Wall Street Journal, December 28, 1999.

${ }^{7}$ Statement by Bank of America's senior vice president of compensation and benefits at a 1993 Conference Board meeting.

${ }^{8}$ One such case is IBM's conversion of its pension plan to a CB format in 1998. After a long legal battle, a ruling by the Seventh Circuit Court of Appeals in 2006 established that IBM's cash balance plan did not discriminate against older employees. In 2007 and 2008, several federal appeals court decisions concluded that cash balance plans do not discriminate on the basis of age. For details, see article by David Pratt in Journal of Pension Benefits, 17:2, 2010.
}

2013 The Clute Institute http://www.cluteinstitute.com/ 
During our sample period, the accounting for pension plans under GAAP is largely governed by SFAS 87 . Under this standard, pension expense for DC plans equals the firm's total contribution to its employees' DC plan accounts. The expense, therefore, always reduces reported net income. The computation of pension expense for DB plans is more complex and is the sum of several components. Service cost and interest cost increase pension expense while expected return on the pension plan assets reduces pension expense. ${ }^{9}$ For firms with overfunded DB plans, it is likely that the expected return on plan assets component of pension expense is sizable. ${ }^{10}$ For many such firms the expected return more than offsets the other components of pension expense, resulting in a pension benefit that increases net income, rather than an expense that reduces it. Prior research documents that managers have strong incentives to report higher income, sometimes sacrificing future cash flows to achieve this objective (see, for instance, Erickson, Hanlon and Maydew, 2004 and Roychowdhury, 2006).

We argue that the financial accounting treatment of DB plans could contribute to the popularity of cash balance plans, and note that CB conversions became popular during the bull market of the mid 1990s, when many DB plans were overfunded and reporting pension income. ${ }^{11}$ Terminating DB plans would result in the loss of this financial reporting benefit. If CB conversions reduce the projected benefit obligation, converters can further boost income in future periods through the amortization of the negative unrecognized prior service cost resulting from the conversion. We add the caveat that financial accounting considerations are likely to be a secondary consideration. Explanations documented in the pension literature, including financial exigency and reducing costs for other reasons (e.g., to increase earnings and the firm's stock price), are more plausible as primary considerations.

\section{Prior Research}

Several streams of pension research provide the framework for this study. In the economics literature, Ippolito (1985) finds support for the "implicit contract" theory, according to which, employees become long-term bondholders of the firm. They have strong incentives to remain with the firm until retirement because their compensation is lower (higher) than their marginal product in the early (later) years of employment. Under normal circumstances, it would not be optimal for firms to violate this implicit contract. Besides incurring reputation costs, violators would have to pay higher wages in the future because employees would refuse to accept less than their marginal product. In the case of pension terminations, prior research has found that firms have breached implicit contracts for reasons of financial exigency. In the context of CB conversions, firms claim that a breach of implicit contracts has not occurred and emphasize that the change is beneficial to employees in an age of greater employee mobility.

Several researchers (e.g., Ippolito, 1986; Stone, 1987; Mittelstaedt, 1989; Thomas, 1989; Petersen, 1992) provide support for two motivations for plan terminations -- financing considerations and tax minimization. Haw et al. (1991) examine the financial characteristics of firms that settle overfunded pension plans without asset reversions. ${ }^{12}$ They find that firms that experience an earnings decline or have restrictive debt covenants are more likely to settle overfunded pension plans, which indicates that settlement transactions are motivated by financial statement concerns.

More recent work (Kapinos, 2012 and 2009; Harper and Treanor, 2011; Coronado and Copeland, 2004; Niehaus and $\mathrm{Yu}, 2004$; Cowan and Power, 2003) directly analyzes potential determinants of the CB plan conversion decision. These studies examine breach of implicit contract, labor market response, or tax avoidance as motives for $\mathrm{CB}$ conversions. Results are mixed and do not point to a single factor driving the decision to convert to a CB plan.

\footnotetext{
${ }^{9}$ Pension expense can include additional components, for example, amortization of prior service costs, which increases pension expense, and net actuarial gains (losses), which reduce (increase) pension expense.

${ }^{10}$ Consistent with this claim, the correlation coefficient between our funding variable and pension expense is - 0.6 in our sample.

${ }^{11}$ For example BusinessWeek reported that, of S\&P 500 firms with DB plans, 31\% reported pension income (as opposed to pension expense) in 1999, 45\% in 2000 and 49\% in 2001. See BusinessWeek August 13, 2001.

${ }^{12}$ Settlements without asset reversions are similar to CB conversions because they do not represent a source of financing for the firm. 
Niehaus and $\mathrm{Yu}$ (2004) argue that the increase in 1990 in the excise tax on excess assets from terminated plans increased the cost of switching from DB to DC plans, creating greater incentives for firms with overfunded DB plans to switch to CB plans instead. Comparing a sample of 123 firms that converted to CB plans to a sample of 77 firms that replaced their DB plans with DC plans, Niehaus and Yu (2004) conclude that the increase in excise tax rates is the primary driver of $\mathrm{CB}$ conversions. They also test, but do not find support for, one prediction of the implicit contract hypothesis, that firms performing poorly are more likely to break their implicit contracts with employees. We argue that the increase in excise taxes is unlikely to be a complete explanation for CB conversions because firms that would have faced the increased taxes on termination could have avoided them by freezing their pension plans instead.

Cowan and Power (2003) examine financial incentives and labor market response as determinants of CB conversions but do not find strong support for their hypotheses. ${ }^{13}$ Coronado and Copeland (2004) attempt to discriminate between $\mathrm{CB}$ conversions being motivated by changes in labor market conditions versus a desire to reduce benefit generosity. They analyze a sample of 75 firms that convert to CB plans matched with firms in similar industries, and conclude that industries with younger, more mobile workers and tighter labor markets have a greater concentration of converters. ${ }^{14}$

Kapinos (2009 and 2012) and Harper and Treanor (2011) also investigate drivers of CB conversions. Using both plan-level and firm-level data in multinomial logit models, they compare CB plans to terminated DB plans and traditional DB plans that remain unchanged. Using a larger sample (251 CB firms and 201 terminated DB firms) than previous studies, Kapinos (2009) finds that plans that cover unionized employees are less likely to be converted to CB or terminated. Inconsistent with Niehaus and Yu (2004) and Harper and Treanor (2011), she documents a negative association between plan funding and the likelihood of CB conversions. Kapinos (2012) examines the association between characteristics of the firm's workforce and CB conversions and the relation between these characteristics and the firm's pension policy. Results do not support breach of implicit contract or labor market response as determinants of $\mathrm{CB}$ conversions.

Extending research by Neihaus and Yu (2004), Harper and Treanor (2011) examine tax avoidance, potential wealth transfer, and financial constraints as determinants of the $\mathrm{CB}$ conversion decision. First, they compare a sample of 129 firms that convert to CB plans (85 firms) or terminate their DB plans (44 firms) with a control sample, matched by industry and size, of up to 310 firms that retain their traditional DB plans. Next, they compare the $85 \mathrm{CB}$ converters and the $44 \mathrm{DB}$ terminators. Their results support tax avoidance and potential wealth transfer (breach of implicit contract) as determinants of the $\mathrm{CB}$ conversion decision.

Our study uses the most comprehensive sample of converters to date, and precise firm-level or pension plan-level data. It differs from prior research in several other key aspects. We compare CB firms to both firms that retain their DB plans and those that terminate or freeze their DB plans and model the decision as a two-stage process. We also examine the timing of $\mathrm{CB}$ conversions and are the first to document the effect of these conversions on the pension obligation and service costs.

\section{SAMPLE SELECTION}

We identify our initial sample of CB firms from multiple sources. First, we perform a word search of firms' SEC filings for mentions of CB pension plan conversions. ${ }^{15}$ We extract the names of additional firms from a list of $\mathrm{CB}$ firms compiled by an employee group that maintains a website with information on CB conversions. ${ }^{16}$ We also

\footnotetext{
13 They compare $86 \mathrm{CB}$ converters to control firms with traditional DB plans, matched by industry and size. One possible explanation for the difference between our results is that we use a larger sample and more direct proxies for some of the hypothesized incentives.

${ }^{14}$ Possible limitations of the Coronado and Copeland (2004) study include the relatively small sample and the use of industrylevel rather than firm-level data to measure most independent variables. Also, their analysis is based on data from randomly selected years because they do not have the actual CB conversion year for most of the sample.

${ }^{15}$ Firms are required to disclose major changes to their pension plans in their SEC filings. A conversion to a CB format is likely to qualify as a major change requiring disclosure.

${ }^{16}$ The website is http://www.cashpensions.org.
}

2013 The Clute Institute http://www.cluteinstitute.com/ 
scan Form 5500, filed by sponsors of pension plans with the DOL, for names of pension plans that contain the term "cash balance." Finally, we identify a few firms from newspaper and other media reports on the CB controversy.

Our sample includes CB conversions that occurred between 1985 and 2002. Our sample period ends shortly after the imposition of the IRS moratorium on CB conversions (the moratorium dramatically reduced the number of such conversions while it was in effect from 2000 to 2007). Pension funding and financial reporting requirements changed significantly after 2006, when PPA 2006 and SFAS 158 came into effect. Consequently, we exclude more recent years from our sample. Table 1 describes our sample selection process. From our initial sample of firms with CB pension plans, we eliminate those that are not publicly traded and are left with a sample of 390 firms. We are able to identify the year of the pension plan conversion for 322 of these firms, and to obtain COMPUSTAT data for 278 firms. These firms constitute our primary CB sample. ${ }^{17}$

Table 1

Sample Selection for Cash Balance and Terminator Samples

Composition of the cash balance sample

Number of publicly traded firms identified as having converted their DB plans to cash balance plans between 1993 and 2002

Less firms where year of conversion could not be determined

Less firms where COMPUSTAT data were not available

Cash balance sample

\section{Composition of the terminating sample}

Number of publicly traded firms identified as having terminated or frozen their DB plans between 1985 and 2002789

Less firms where COMPUSTAT data were not available

To construct our comparison samples, we first identify all firms with DB plans from Form 5500 filings for 1998 and 1999. Using the COMPUSTAT database, we determine the identity of the publicly traded firms that sponsor these DB plans. We then exclude firms identified as CB firms and firms that have frozen or terminated their DB plans, which yields a sample of 1,026 firms that have retained their traditional DB plans. Using a random number generator, we assign years randomly to these firms, so that the proportion of the control sample in each year equals that of the CB sample in the same year.

To identify the sample of firms that have terminated or frozen their DB plans, we search the NAARS database of annual reports for the 1985-1994 period and SEC filings for years after 1994 for occurrences of 'terminate,' 'freeze' or 'suspend' (or variations thereof) in the vicinity of the word 'pension. ${ }^{18}$ After excluding firms for which the terminations or freezes occurred outside the 1985-2002 window and firms for which data were not available on COMPUSTAT, our terminating sample includes 692 firms. In our univariate tests we use a matchedpair design, to better control for industry and size effects that could otherwise drive some results. This "matched sample" consists of pairs of CB and traditional DB or terminating firms, where firms are matched on industry, as defined by SIC code, and size.

We obtain accounting data from the COMPUSTAT database, pension plan data from the DOL Form 5500 filings and unemployment rates from the Bureau of Labor Statistics. ${ }^{19}$

\footnotetext{
${ }^{17}$ To the best of our knowledge this is the most comprehensive sample of conversions to CB plans used in any study. In comparison, Cowan and Power (2003), Coronado and Copeland (2004), Niehaus and Yu (2004), Kapinos (2009 and 2012), and Harper and Treanor (2011) use samples of 86, 75, 123, 251, and 85 CB firms.

${ }^{18}$ If a firm first froze and then terminated its pension plan, we regard the date of the freeze as the relevant date.

${ }^{19}$ Due to a two to three-year lag in the availability of Form 5500 data from the DOL, 2002 was the most recent year for which Form 5500 data were available when the data were extracted.
} 


\section{DESCRIPTIVE STATISTICS AND UNIVARIATE COMPARISONS}

\section{Industry Composition}

We use two-digit SIC codes to assign sample firms to 68 industry classifications. Table 2 presents statistics on the distribution of $\mathrm{CB}$ and control samples across industries. The distribution across industries is generally similar across samples, but a few differences are apparent. CB converters are disproportionately represented in the banking, utility, insurance and business services industries. Firms that froze or terminated their pension plans show some concentration in the banking and business services industries while firms that retained their DB plans show some concentration in transportation equipment and food and kindred products.

Table 2

Distribution of Sample across Industries

\begin{tabular}{|c|c|c|c|c|c|c|c|}
\hline \multirow[t]{2}{*}{\begin{tabular}{|l|} 
Two digit \\
SIC code
\end{tabular}} & \multirow[t]{2}{*}{ SIC Code description } & \multicolumn{2}{|c|}{ CB Sample } & \multicolumn{2}{|c|}{ Traditional DB Sample } & \multicolumn{2}{|c|}{ Terminating Sample } \\
\hline & & No. & $\begin{array}{c}\% \text { of CB } \\
\text { sample }\end{array}$ & No. & $\begin{array}{l}\% \text { of DB } \\
\text { sample }\end{array}$ & No. & $\begin{array}{c}\% \text { of } \\
\text { terminating } \\
\text { sample }\end{array}$ \\
\hline 1 & Agriculture production - crops & 2 & 0.5 & 3 & 0.3 & 4 & 0.5 \\
\hline 2 & Agricultural produce-livestock,dairy & 0 & 0 & 1 & 0.1 & 0 & 0 \\
\hline 7 & Agriculture services & 0 & 0 & 1 & 0.1 & 0 & 0 \\
\hline 10 & Metal mining & 1 & 0.3 & 4 & 0.4 & 5 & 0.6 \\
\hline 12 & Coal mining & 2 & 0.5 & 2 & 0.2 & 1 & 0.1 \\
\hline 13 & Oil and gas extraction & 1 & 0.3 & 18 & 1.8 & 23 & 2.9 \\
\hline 14 & Mining, quarry non-metallic minerals & 0 & 0 & 4 & 0.4 & 1 & 0.1 \\
\hline 15 & Bldg. Construction-general contractor & 2 & 0.5 & 2 & 0.2 & 5 & 0.6 \\
\hline 16 & Heavy construction excl. buildings & 2 & 0.5 & 1 & 0.1 & 1 & 0.1 \\
\hline 17 & Construction-special trade & 0 & 0 & 1 & 0.1 & 2 & 0.3 \\
\hline 20 & Food and kindred products & 7 & 1.8 & 44 & 4.3 & 12 & 1.5 \\
\hline 21 & Tobacco products & 1 & 0.3 & 5 & 0.5 & 1 & 0.1 \\
\hline 22 & Textile mill products & 1 & 0.3 & 12 & 1.2 & 11 & 1.4 \\
\hline 23 & Apparel and other finished products & 3 & 0.8 & 15 & 1.5 & 12 & 1.5 \\
\hline 24 & Lumber\&wood products excl. furniture & 1 & 0.3 & 6 & 0.6 & 4 & 0.5 \\
\hline 25 & Furniture and fixtures & 2 & 0.5 & 14 & 1.4 & 7 & 0.9 \\
\hline 26 & Paper and allied products & 6 & 1.5 & 26 & 2.5 & 7 & 0.9 \\
\hline 27 & Printing, publishing $\&$ allied & 9 & 2.3 & 22 & 2.1 & 17 & 2.2 \\
\hline 28 & Chemicals \& allied products & 22 & 5.6 & 68 & 6.6 & 27 & 3.4 \\
\hline 29 & Petroleum refining \& related industries & 6 & 1.5 & 14 & 1.4 & 3 & 0.4 \\
\hline 30 & Rubber \& misc. plastic products & 7 & 1.8 & 30 & 2.9 & 16 & 2.0 \\
\hline 31 & Leather \& leather products & 0 & 0 & 6 & 0.6 & 4 & 0.5 \\
\hline 32 & Stone, clay, glass \& concrete products & 4 & 1.0 & 18 & 1.8 & 8 & 1.0 \\
\hline 33 & Primary metal industries & 8 & 2.1 & 34 & 3.3 & 15 & 1.9 \\
\hline 34 & Fabricated metal excluding machinery & 14 & 3.6 & 38 & 3.7 & 23 & 2.9 \\
\hline 35 & Industrial, comm. m/c, computer eqpt. & 20 & 5.1 & 65 & 6.3 & 50 & 6.4 \\
\hline 36 & Electrical equipment excl. computers & 18 & 4.6 & 44 & 4.3 & 37 & 4.7 \\
\hline 37 & Transportation equipment & 11 & 2.8 & 56 & 5.5 & 12 & 1.5 \\
\hline 38 & Measuring instr., photo gds, watches & 14 & 3.6 & 33 & 3.2 & 15 & 1.9 \\
\hline 39 & Misc. manufacturing industries & 2 & 0.5 & 13 & 1.3 & 9 & 1.1 \\
\hline 40 & Railroad transportation & 0 & 0 & 5 & 0.5 & 4 & 0.5 \\
\hline 41 & Transit \& passenger transport & 0 & 0 & 1 & 0.1 & 0 & 0 \\
\hline 42 & Motor freight, transport, warehousing & 0 & 0 & 6 & 0.6 & 4 & 0.5 \\
\hline 44 & Water transportation & 1 & 0.3 & 3 & 0.3 & 4 & 0.5 \\
\hline 45 & Transportation by air & 0 & 0 & 7 & 0.7 & 8 & 1.0 \\
\hline 47 & Transportation services & 2 & 0.5 & 3 & 0.3 & 1 & 0.1 \\
\hline 48 & Communications & 16 & 4.1 & 38 & 3.7 & 13 & 1.7 \\
\hline 49 & Electric, gas, sanitary services & 47 & 12.1 & 82 & 8.0 & 16 & 2.0 \\
\hline 50 & Durable goods - wholesale & 6 & 1.5 & 22 & 2.1 & 24 & 3.0 \\
\hline
\end{tabular}

2013 The Clute Institute http://www.cluteinstitute.com/ 


\begin{tabular}{|c|c|c|c|c|c|c|c|}
\hline \multirow{2}{*}{\begin{tabular}{|c|}
$\begin{array}{l}\text { Two digit } \\
\text { SIC code }\end{array}$ \\
51 \\
\end{tabular}} & \multirow{2}{*}{\begin{tabular}{|l|} 
SIC Code description \\
Non-durable goods-wholesale \\
\end{tabular}} & \multicolumn{2}{|c|}{ CB Sample } & \multicolumn{2}{|c|}{ Traditional DB Sample } & \multicolumn{2}{|c|}{ Terminating Sample } \\
\hline & & 5 & 1.3 & 18 & 1.8 & 17 & 2.2 \\
\hline 52 & Bldg material, hardware, grdn - retail & 1 & 0.3 & 0 & 0.0 & 5 & 0.6 \\
\hline 53 & General merchandise stores & 7 & 1.8 & 7 & 0.7 & 14 & 1.8 \\
\hline 54 & Food stores & 7 & 1.8 & 18 & 1.8 & 5 & 0.6 \\
\hline 55 & Auto dealers, gas stations & 0 & 0 & 2 & 0.2 & 4 & 0.5 \\
\hline 56 & Apparel \& accessory stores & 2 & 0.5 & 3 & 0.3 & 7 & 0.9 \\
\hline 57 & Home furniture \& equipment stores & 0 & 0 & 2 & 0.2 & 4 & 0.5 \\
\hline 58 & Eating and drinking places & 6 & 1.5 & 5 & 0.5 & 4 & 0.5 \\
\hline 59 & Miscellaneous retail & 4 & 1.0 & 7 & 0.7 & 15 & 1.9 \\
\hline 60 & Depository institutions & 50 & 12.8 & 79 & 7.7 & 149 & 18.9 \\
\hline 61 & Non-depository credit institutions & 7 & 1.8 & 10 & 1.0 & 9 & 1.1 \\
\hline 62 & Security \& commodity brokers & 1 & 0.3 & 5 & 0.5 & 10 & 1.3 \\
\hline 63 & Insurance carriers & 26 & 6.7 & 32 & 3.1 & 25 & 3.2 \\
\hline 64 & Insurance agents, brokers \& service & 4 & 1.0 & 6 & 0.6 & 6 & 0.8 \\
\hline 65 & Real estate & 1 & 0.3 & 5 & 0.5 & 8 & 1.0 \\
\hline 66 & Combined real estate and insurance & 0 & 0 & 0 & 0 & 2 & 0.3 \\
\hline 67 & Holding, other investment offices & 4 & 1.0 & 16 & 1.6 & 17 & 2.2 \\
\hline 70 & Hotels, other lodging places & 3 & 0.8 & 3 & 0.3 & 7 & 0.9 \\
\hline 72 & Personal services & 2 & 0.5 & 2 & 0.2 & 3 & 0.4 \\
\hline 73 & Business services & 15 & 3.8 & 18 & 1.8 & 37 & 4.7 \\
\hline 75 & Auto repair, services, parking & 2 & 0.5 & 2 & 0.2 & 1 & 0.1 \\
\hline 76 & Miscellaneous repair services & 0 & 0 & 0 & 0 & 10 & 1.3 \\
\hline 78 & Motion pictures & 0 & 0 & 2 & 0.2 & 4 & 0.5 \\
\hline 79 & Amusements, recreation & 0 & 0 & 2 & 0.2 & 4 & 0.5 \\
\hline 80 & Health services & 3 & 0.8 & 1 & 0.1 & 9 & 1.1 \\
\hline 82 & Educational services & 1 & 0.3 & 0 & 0 & 2 & 0.3 \\
\hline 87 & $\begin{array}{l}\text { Engineering, accounting., R\&D, mgmt. \& } \\
\text { public relations services }\end{array}$ & 1 & 0.3 & 7 & 0.7 & 12 & 1.5 \\
\hline 89 & Services, miscellaneous & 0 & 0 & 0 & 0 & 1 & 0.1 \\
\hline 99 & Non-classifiable establishments & 0 & 0 & 7 & 0.7 & 4 & 0.5 \\
\hline & Totals & 390 & $100 \%$ & 1026 & $100 \%$ & 789 & $100 \%$ \\
\hline
\end{tabular}

\section{Year of Conversion to CB Plans or Plan Termination}

Table 3 reveals the number of conversions to CB plans by year. The earliest conversion in our sample is by Bank of America in 1985. The largest number of conversions (19) in the first ten years was in 1989, which is shortly after SFAS 87 "Employers' Accounting for Pensions" became effective for most firms. This standard changed the measurement of the pension expense and the pension obligation for most firms, and could have motivated some to make pension plan modifications. The Tax Reform Act of 1986 and the Omnibus Budget Reconciliation Act of 1987 are also likely to have played a role in changing the pension landscape. ${ }^{20}$ The number of CB conversions declined in subsequent years before accelerating in the mid-nineties. The observed increase could be related to the boom in the capital markets during this period, which caused many pension plans to become overfunded. In the period 1985 to 1999 , there is a correlation of 0.93 between the year-end level of the S\&P 500 index and the number of CB conversions in the year. The dramatic decline in the number of conversions since 1999 could be due to the Treasury moratorium imposed in 1999 and/or the adverse publicity surrounding CB conversions. ${ }^{21}$ In contrast, terminations of DB plans appear to have been more popular in the early years of our sample period, the mid to late $1980 \mathrm{~s}$, and their number has declined in the later part of our sample period.

\footnotetext{
${ }^{20}$ The tax reform act of 1986 applied a 10 percent excise tax on surplus assets when overfunded plans were terminated. This made pension terminations more costly and may have increased the attractiveness of $\mathrm{CB}$ conversions as an alternative. The Omnibus Budget Reconciliation Act of 1987 (OBRA87) lowered the maximum limit up to which contributions by the employer to pension plans are tax deductible to $150 \%$ of the current liability.

${ }^{21}$ Companies could adopt the CB format while the moratorium was in effect. However, they did not receive the approval of the IRS, and might have been subject to back taxes and penalties. 
Table 3

Cash Balance Conversions and Pension Plan Terminations by Year

\begin{tabular}{|c|c|c|c|c|}
\hline Year & $\begin{array}{c}\text { Number of CB } \\
\text { Conversions }\end{array}$ & $\begin{array}{c}\text { Percentage of Total } \\
\text { CB Conversions }\end{array}$ & $\begin{array}{c}\text { Number of } \\
\text { Terminations }\end{array}$ & $\begin{array}{c}\text { Percentage of Total } \\
\text { Terminations }\end{array}$ \\
\hline 1985 & 2 & 0.6 & 77 & 9.8 \\
\hline 1986 & 6 & 1.9 & 56 & 7.1 \\
\hline 1987 & 8 & 2.5 & 53 & 6.7 \\
\hline 1988 & 7 & 2.2 & 83 & 6.5 \\
\hline 1989 & 19 & 5.9 & 48 & 5.1 \\
\hline 1990 & 7 & 2.2 & 40 & 4.7 \\
\hline 1991 & 4 & 1.2 & 37 & 5.3 \\
\hline 1992 & 13 & 4.0 & 42 & 4.8 \\
\hline 1993 & 9 & 2.8 & 38 & 5.6 \\
\hline 1994 & 12 & 3.7 & 44 & 46 \\
\hline 1995 & 17 & 5.3 & 53 & 6.7 \\
\hline 1996 & 30 & 9.3 & 52 & 6.6 \\
\hline 1997 & 44 & 13.6 & 45 & 5.7 \\
\hline 1998 & 51 & 15.8 & 31 & 3.9 \\
\hline 1999 & 44 & 13.6 & 23 & 2.9 \\
\hline 2000 & 26 & 8.1 & 21 & \\
\hline 2001 & 11 & 3.4 & 10 & \\
\hline
\end{tabular}

The sample includes the 322 conversions to cash balance plans between 1985 and 2002 for which the year of the conversion could be determined. The terminating sample includes 789 freezes or terminations of DB plans between 1985 and 2002 for which the year of freeze or termination could be determined.

\section{Univariate Comparisons}

Table 4 presents results of univariate tests for differences in selected characteristics between matched pairs of CB and control firms. Panel A tests for differences between CB firms and firms that retained their traditional DB plans. Panel B compares CB firms with firms that terminated or froze their DB plans. In both cases firms were matched on industry and on firm size. In addition, in panel B, firms were matched on the year of change (the year of conversion for the CB sample and the year of termination for the termination sample).

Table 4

Univariate Tests for Matched-Pair Differences between Cash Balance and Control Firms

\begin{tabular}{|c|c|c|c|c|c|c|}
\hline \multicolumn{7}{|c|}{ Panel A: Cash balance firms and firms that retain their traditional DB plans } \\
\hline Variable/Ratio & Sample & Mean & $75 \%$ & Median & $25 \%$ & $\mathbf{N}$ \\
\hline \multirow[t]{2}{*}{ YEARS_TO_RETIRE } & $\mathrm{CB}$ & $3.429 * * *$ & 4.527 & $3.119^{\# \# \#}$ & 1.340 & 127 \\
\hline & DB & $4.974 * * *$ & 5.725 & $4.053^{\# \# \#}$ & 2.123 & 127 \\
\hline \multirow[t]{2}{*}{ ACTIVE } & $\mathrm{CB}$ & 0.583 & 0.717 & $0.561^{\# \#}$ & 0.470 & 112 \\
\hline & DB & 0.613 & 0.739 & $0.647^{\# \#}$ & 0.516 & 112 \\
\hline \multirow[t]{2}{*}{ TURNOVER } & $\mathrm{CB}$ & 0.109 & 0.155 & 0.088 & 0.046 & 110 \\
\hline & DB & 0.105 & 0.135 & 0.084 & 0.049 & 110 \\
\hline \multirow[t]{2}{*}{ SERVCOST (\%) } & $\mathrm{CB}$ & 0.64 & 0.74 & 0.52 & 0.30 & 161 \\
\hline & DB & 0.57 & 0.70 & 0.51 & 0.28 & 161 \\
\hline \multirow[t]{2}{*}{ PENSEXP (\%) } & $\mathrm{CB}$ & 0.475 & 0.798 & 0.425 & 0.107 & 213 \\
\hline & DB & 0.506 & 0.811 & 0.448 & 0.157 & 213 \\
\hline \multirow[t]{2}{*}{ LABINT } & $\mathrm{CB}$ & 0.67 & 0.90 & 0.71 & 0.44 & 236 \\
\hline & DB & 0.68 & 0.92 & 0.72 & 0.46 & 236 \\
\hline \multirow[t]{2}{*}{ FUNDING } & $\mathrm{CB}$ & $0.106^{* *}$ & 0.202 & $0.057^{\# \#}$ & -0.067 & 183 \\
\hline & DB & $0.040 * *$ & 0.170 & $0.040^{\# \#}$ & -0.127 & 183 \\
\hline \multirow[t]{2}{*}{ INTCOV } & $\mathrm{CB}$ & $7.66 * *$ & 6.62 & $3.63^{\#}$ & 1.97 & 194 \\
\hline & DB & $15.91 * *$ & 9.16 & $4.50^{\#}$ & 2.25 & 194 \\
\hline \multirow[t]{2}{*}{ ROE (\%) } & $\mathrm{CB}$ & 7.42 & 16.11 & $11.48^{\# \#}$ & 7.28 & 235 \\
\hline & DB & 10.08 & 16.83 & $13.18^{\# \#}$ & 9.59 & 235 \\
\hline
\end{tabular}

2013 The Clute Institute http://www.cluteinstitute.com/ 


\begin{tabular}{|c|c|c|c|c|c|c|}
\hline Variable/Ratio & Sample & Mean & $75 \%$ & Median & $25 \%$ & $\mathbf{N}$ \\
\hline \multirow{2}{*}{ Return on assets (\%) } & $\mathrm{CB}$ & 4.2 & 6.9 & $4.7^{\# \#}$ & 1.3 & 251 \\
\hline & DB & 4.8 & 7.3 & $4.9^{\# \#}$ & 1.6 & 251 \\
\hline \multirow[t]{2}{*}{ SIZE } & $\mathrm{CB}$ & $7.91 * * *$ & 9.03 & $7.75^{\text {\#\#\# }}$ & 6.73 & 253 \\
\hline & DB & $7.59 * * *$ & 8.86 & $7.43^{\# \# \#}$ & 6.15 & 253 \\
\hline \multirow{2}{*}{$\begin{array}{l}\text { Logarithm of market } \\
\text { capitalization }\end{array}$} & $\mathrm{CB}$ & 7.22 & 8.60 & 7.24 & 5.92 & 193 \\
\hline & DB & 7.09 & 8.30 & 7.01 & 5.87 & 193 \\
\hline \multirow[t]{2}{*}{ Number of employees } & $\mathrm{CB}$ & 21,708 & 22,400 & $7,056^{\# \#}$ & 2,825 & 218 \\
\hline & DB & 19,371 & 17,240 & $6,068^{\# \#}$ & 2,178 & 218 \\
\hline \multirow{2}{*}{ Pension discount rate $(\%)$} & $\mathrm{CB}$ & 7.41 & 7.75 & 7.25 & 7.00 & 129 \\
\hline & DB & 7.45 & 7.75 & 7.50 & 7.00 & 129 \\
\hline \multirow{2}{*}{$\begin{array}{l}\text { Assumed rate of } \\
\text { compensation increase }\end{array}$} & $\mathrm{CB}$ & 4.74 & 5.00 & 4.70 & 4.46 & 103 \\
\hline & DB & 4.70 & 5.00 & 4.75 & 4.30 & 103 \\
\hline \multirow{2}{*}{$\begin{array}{l}\text { Assumed long-term return } \\
\text { on plan assets }\end{array}$} & $\mathrm{CB}$ & $8.99 * *$ & 9.50 & $9.00^{\# \#}$ & 8.75 & 120 \\
\hline & DB & $8.74 * *$ & 9.25 & $9.00^{\# \#}$ & 8.25 & 120 \\
\hline \multirow[t]{2}{*}{$\mathrm{PBO}$} & $\mathrm{CB}$ & 0.204 & 0.228 & 0.101 & 0.030 & 184 \\
\hline & DB & 0.152 & 0.203 & 0.097 & 0.031 & 184 \\
\hline
\end{tabular}

Panel B: Cash balance firms and firms that terminate their DB plans

\begin{tabular}{|c|c|c|c|c|c|c|}
\hline Variable/Ratio & Sample & Mean & $75 \%$ & Median & $25 \%$ & $\mathbf{N}$ \\
\hline \multirow[t]{2}{*}{ YEARS_TO_RETIRE } & $\mathrm{CB}$ & 3.280 & 4.549 & $3.098^{\#}$ & 1.087 & 39 \\
\hline & Terminators & 4.401 & 6.640 & $3.403^{\#}$ & 1.202 & 39 \\
\hline \multirow[t]{2}{*}{ ACTIVE } & $\mathrm{CB}$ & 0.599 & 0.725 & 0.617 & 0.477 & 20 \\
\hline & Terminators & 0.645 & 0.837 & 0.729 & 0.548 & 20 \\
\hline \multirow[t]{2}{*}{ TURNOVER } & $\mathrm{CB}$ & 0.097 & 0.143 & 0.101 & 0.050 & 19 \\
\hline & Terminators & 0.114 & 0.104 & 0.084 & 0.016 & 19 \\
\hline \multirow[t]{2}{*}{ SERVCOST (\%) } & $\mathrm{CB}$ & 0.58 & 0.74 & 0.52 & 0.33 & 47 \\
\hline & Terminators & 0.49 & 0.68 & 0.32 & 0.14 & 47 \\
\hline \multirow{2}{*}{ PENSEXP (\%) } & $\mathrm{CB}$ & 0.483 & 0.955 & 0.589 & 0.255 & 73 \\
\hline & Terminators & 0.648 & 0.885 & 0.375 & 0.180 & 73 \\
\hline \multirow[t]{2}{*}{ LABINT } & $\mathrm{CB}$ & 0.75 & 0.98 & 0.77 & 0.66 & 97 \\
\hline & Terminators & 0.76 & 0.97 & 0.82 & 0.58 & 97 \\
\hline \multirow[t]{2}{*}{ FUNDING } & $\mathrm{CB}$ & $0.69 * * *$ & 0.146 & $0.042^{\# \# \#}$ & -0.085 & 56 \\
\hline & Terminators & $-0.097 * * *$ & 0.031 & $-0.085_{\text {\#\# }}$ & -0.226 & 56 \\
\hline \multirow[t]{2}{*}{ INTCOV } & $\mathrm{CB}$ & 13.3 & 8.6 & $4.4^{\mathrm{\# \#}}$ & 2.8 & 70 \\
\hline & Terminators & 5.6 & 6.9 & $2.2^{\# \#}$ & -0.6 & 70 \\
\hline \multirow[t]{2}{*}{ ROE (\%) } & $\mathrm{CB}$ & 0.25 & 17.7 & $12.5^{\# \#}$ & 5.9 & 101 \\
\hline & Terminators & -10.8 & 15.5 & $9.7^{\# \#}$ & 1.7 & 101 \\
\hline \multirow[t]{2}{*}{ Return on assets (\%) } & $\mathrm{CB}$ & $4.85 * * *$ & 7.67 & $4.46^{\# \#}$ & 1.20 & 101 \\
\hline & Terminators & $0.71 * * *$ & 5.52 & $2.15^{\# \#}$ & 0.62 & 101 \\
\hline \multirow[t]{2}{*}{ SIZE } & $\mathrm{CB}$ & 7.86 *** & 8.99 & $7.85^{\# \# \#}$ & 6.73 & 101 \\
\hline & Terminators & $6.31 * * *$ & 7.71 & $6.36^{\# \# \#}$ & 4.81 & 101 \\
\hline \multirow{2}{*}{$\begin{array}{l}\text { Logarithm of market } \\
\text { capitalization }\end{array}$} & $\mathrm{CB}$ & $7.20 * * *$ & 8.57 & 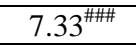 & 5.55 & 79 \\
\hline & Terminators & $5.40 * * *$ & 6.63 & $5.31^{\# \# \#}$ & 4.19 & 79 \\
\hline \multirow[t]{2}{*}{ Number of employees } & $\mathrm{CB}$ & $21,235 * * *$ & 24,700 & $7,461^{\# \# \#}$ & 2,800 & 82 \\
\hline & Terminators & $4,768 * * *$ & 6,335 & $1,516^{\# \# \#}$ & 400 & 82 \\
\hline \multirow[t]{2}{*}{ Pension discount rate $(\%)$} & $\mathrm{CB}$ & 7.34 & 7.50 & 7.25 & 7.00 & 37 \\
\hline & Terminators & 7.22 & 7.50 & 7.25 & 7.00 & 37 \\
\hline \multirow{2}{*}{$\begin{array}{l}\text { Assumed rate of } \\
\text { compensation increase }\end{array}$} & $\mathrm{CB}$ & 4.7 & 5.0 & 4.7 & 4.5 & 25 \\
\hline & Terminators & 4.4 & 5.0 & 4.5 & 4.0 & 25 \\
\hline \multirow{2}{*}{$\begin{array}{l}\text { Assumed long-term return } \\
\text { on plan assets }\end{array}$} & $\mathrm{CB}$ & 8.70 & 9.23 & 9.00 & 8.13 & 36 \\
\hline & Terminators & 8.61 & 9.00 & 8.75 & 8.00 & 36 \\
\hline \multirow[t]{2}{*}{ PBO } & $\mathrm{CB}$ & $0.180 * * *$ & 0.255 & $0.103 \# \# \#$ & 0.043 & 56 \\
\hline & Terminators & $0.098 * * *$ & 0.109 & $0.045 \# \# \#$ & 0.015 & 56 \\
\hline
\end{tabular}

Notes: We selected control firms by matching on industry and on firm size, as measured by total assets. In addition, in panel B, firms were also matched on the year of change (conversion or termination). The CB firm sample is not identical in panels A and $\mathrm{B}$ because we identified fewer matches for firms that froze or terminated DB plans in the same year. The data pertain to the year 
prior to the change. We test for differences between cash balance and control firms using the paired t-test and the Wilcoxon signed rank test.

\begin{tabular}{|c|c|}
\hline$* *, * *, *$ & $\begin{array}{l}\text { Difference in means between matched firms significant at the } 1 \% \text { level, } 5 \% \text { level, and } 10 \% \text { level, } \\
\text { respectively, in paired t-tests. }\end{array}$ \\
\hline \#\#\#, \#\#, \# & $\begin{array}{l}\text { Difference between matched firms significant at the } 1 \% \text { level, } 5 \% \text { level, and } 10 \% \text { level, respectively, in the } \\
\text { Wilcoxon signed rank tests. }\end{array}$ \\
\hline EARS_ & $\begin{array}{l}\text { IRE }=\log (\text { projected benefit obligation/accumulated benefit obligation }) / \log (1+\text { Compinc), where Compinc is } \\
\text { the firm's assumed rate of compensation increase. If Compinc is missing, it is set to the sample median. }\end{array}$ \\
\hline ACTIVE & $=$ the ratio of active participants to total participants in the firm's pension plans. \\
\hline TURNOVER & $\begin{array}{l}=\text { the ratio of the number of plan participants who separated from the firm to the total number of plan } \\
\text { participants. }\end{array}$ \\
\hline SERVCOST & $=$ the ratio of the pension service cost to revenue for the year. \\
\hline PENSEXP & $=$ the ratio of pension expense to sales revenue. \\
\hline LABINT & $=1-$ the ratio of fixed to total assets \\
\hline FUNDING & $=($ plan assets - projected benefit obligation $) /$ projected benefit obligation. \\
\hline INTCOV & $=$ the interest coverage ratio \\
\hline ROE & $=$ the return on equity \\
\hline SIZE & $=$ the natural logarithm of total assets of the firm at year end. \\
\hline PBO & $=$ the ratio of the projected benefit obligation to total firm assets \\
\hline
\end{tabular}

\section{Comparison of CB firms to Firms that Retain Traditional DB Plans}

We use two proxies for employee age distribution: YEARS-TO_RETIRE (capturing the average number of future years of service for the representative employee) and ACTIVE (the ratio of active to total plan participants). ${ }^{22}$ Results in Panel A of Table 4 indicate that employees at CB firms are, on average, closer to retirement than those at control firms that retain their traditional DB plans. YEARS_TO_RETIRE is significantly lower for CB firms at better than the $1 \%$ level in the t-test and the Wilcoxon signed rank test. ACTIVE is significantly lower for the CB sample in the Wilcoxon test. We do not find significant differences in employee turnover. ${ }^{23}$ These preliminary findings are consistent with the breach of implicit contract hypothesis and provide no evidence that the conversion decision is a response to the needs of a younger, more mobile workforce.

Also consistent with arguments in past literature that financial exigency is often associated with breach of implicit contract with employees, we find that $\mathrm{CB}$ firms are less profitable than control firms (median ROE and ROA of $11.48 \%$ and $4.7 \%$ versus $13.18 \%$ and $4.9 \%$, significant at the $5 \%$ level) and have significantly lower interest coverage ratios than control firms.

Univariate tests provide no evidence that the conversion decision is linked to the magnitude of service costs (SERVCOST), pension expense (PENSEXP), or labor intensity (LABINT) ${ }^{24}$ Statistically significant differences in SIZE and number of employees indicate that CB firms are larger than control firms, even after matching on size. One explanation for this finding is that fixed costs associated with $\mathrm{CB}$ conversions act as a deterrent for smaller firms. However, market capitalization does not differ significantly between the matched pairs, perhaps because of the lower profitability of CB firms.

The mean assumed long-term rate of return on plan assets used by CB firms is marginally higher (more aggressive) than that used by control firms. However, we find no significant differences across CB and control firms in the pension discount rate or compensation increase rate assumptions, or in the ratio of projected pension obligation scaled by total assets (PBO).

22 YEARS_TO_RETIRE is measured as $\log$ (ratio of projected benefit obligation to accumulated benefit obligation $) / \log (1+$ assumed rate of compensation increase). Subramanyam and Zhang (2000) use this variable to proxy for average years to retirement.

${ }^{23}$ TURNOVER is measured as the ratio of the number of plan participants who separated from the firm to the total number of plan participants.

${ }^{24}$ LABINT is measured as 1- the ratio of fixed to total assets at year end. Cheng and Warfield (2005) use a similar variable to proxy for labor intensity. Pension costs are more likely to be salient for firms with high labor intensity.

2013 The Clute Institute http://www.cluteinstitute.com/ 


\section{Comparison of CB Firms to Firms that Terminate DB Plans}

Panel B of Table 4 indicates that CB firms have workforces that are marginally closer to retirement, on average, than firms that terminate their DB plans. Their pension plans are also better funded. CB conversions are likely to be more attractive than terminations for firms with overfunded DB plans either because excise taxes make termination more costly and/or because retaining a DB format offers greater financial reporting benefits for these firms. CB firms are more profitable as measured both by ROE and return on assets, and their interest coverage ratios are higher than those of the terminators. These results are consistent with prior research that finds that pension plan terminations are often a response to financial distress and with the breach of implicit contracts theory that suggests that financial exigency can be used to justify such breaches. CB firms are larger than terminators when size is measured by total assets, market capitalization or number of employees, which may be due to sizable fixed costs associated with conversion and/or larger political costs borne by larger firms if they terminate DB plans. PBO is significantly larger for CB firms, suggesting greater employee resistance if DB plans were terminated instead.

Overall, the univariate results document that $\mathrm{CB}$ firms are less profitable than firms that retain their DB plans but more profitable than firms that terminate their plans. They have workforces closer to retirement than firms that retain their DB plans, consistent with the argument that the benefits from breaching the implicit contract might be higher for CB firms than for those retaining traditional DB plans. Finally, the pension plan obligation is larger for $\mathrm{CB}$ firms than for terminators. To the extent that this variable is a proxy for the value that employees place on the pension plan, $\mathrm{CB}$ firms might face greater employee resistance to terminations. Taken together, the univariate results provide evidence that $\mathrm{CB}$ conversions might represent a more moderate breach of implicit contract than DB plan terminations.

\section{HECKMAN SELECTION MODEL ESTIMATION OF PENSION PLAN CHOICES}

We next attempt to determine if the inferences drawn from our univariate analyses hold in multivariate estimations. CB conversions as well as terminations represent decisions to switch away from the traditional defined benefit plan structure, and our earlier analyses indicate that both choices are consistent with the breach of implicit contract hypothesis, albeit not to the same degree. We model the decision as a two-stage process using the Heckman selection model. The first stage analyzes the determinants of the decision to switch away from traditional DB plans. Contingent on this choice, the second stage investigates the CB conversion vs. DB plan termination choice. ${ }^{25}$ That is, after the firm decides to switch away from a traditional DB plan, it then decides whether to convert to CB or terminate the DB plan. ${ }^{26}$

The breach of implicit contract hypothesis would lead us to predict, consistent with our earlier arguments and with past literature, that firms that switch away from traditional DB plans either by converting to CB plans or terminating DB plans are less profitable, have a workforce closer to retirement age, have larger pension costs, and expect less employee backlash as a result of the change. Results are largely consistent with these predictions.

We use ROE as a proxy for firm profitability. The coefficient on ROE in the first stage of the Heckman selection model estimation (Panel A of Table 5) is negative and highly significant. We find compelling evidence that less profitable firms are more likely to terminate DB plans or convert to CB plans, consistent with arguments in past literature (e.g., Thomas 1989) that firms are more likely to break the terms of the implicit contracts with employees when they are experiencing financial difficulties.

\footnotetext{
${ }^{25}$ Data limitations reduce the sample size to 600 observations for the first stage of the Heckman selection model estimation. See Van De Ven and Van Praag (1981) for more information about Heckman selection model estimation.

${ }^{26}$ Some, but not all, firms replace their terminated DB plans with defined contribution plans. Due to data limitations, identifying these plans is not straightforward. To avoid drawing incorrect inferences, we do not make any assumptions about whether firms replaced their terminated DB plans.
} 


\section{Table 5}

Estimation of Pension Plan Change Decisions Using Heckman Selection Model

(Two-tailed $\mathrm{p}$-values in parentheses)

Panel A: Stage 1: Decision to switch away from traditional defined benefit plan (CHANGE $=0$ for firms that retain traditional DB plans; 1 for terminators or CB firms)

\begin{tabular}{|c|c|c|}
\hline Variable & $\begin{array}{c}\text { Predicted } \\
\text { Sign }\end{array}$ & $\begin{array}{c}\text { Coefficient } \\
\text { (p-value) }\end{array}$ \\
\hline Intercept & $?$ & $\begin{array}{l}-0.077 \\
(-0.20)\end{array}$ \\
\hline ROE & - & $\begin{array}{c}-0.762 \\
(0.0001)\end{array}$ \\
\hline YEARS_TO_RETIRE & - & $\begin{array}{l}-0.034 \\
(0.03)\end{array}$ \\
\hline SERVCOST & + & $\begin{array}{c}30.514 \\
(0.10)\end{array}$ \\
\hline LABINT & + & $\begin{array}{l}0.471 \\
(0.05) \\
\end{array}$ \\
\hline UNEMP & + & $\begin{array}{l}-0.049 \\
(0.18)\end{array}$ \\
\hline PBO & - & $\begin{array}{l}-1.483 \\
(0.002)\end{array}$ \\
\hline FUNDING & $?$ & $\begin{array}{l}-0.338 \\
(0.08) \\
\end{array}$ \\
\hline SIZE & $?$ & $\begin{array}{l}0.017 \\
(0.61)\end{array}$ \\
\hline No. of observations & & 600 \\
\hline Obs. with CHANGE $=1$ & & 258 \\
\hline Obs. with CHANGE $=0$ & & 342 \\
\hline
\end{tabular}

Panel B: Stage 2: Choice between cash balance conversion $(\mathrm{CB}=1)$ and termination $(\mathrm{CB}=0)$, given that $\mathrm{CHANGE}=1$ in Stage 1

\begin{tabular}{|c|c|c|}
\hline Variable & $\begin{array}{c}\text { Predicted } \\
\text { Sign }\end{array}$ & $\begin{array}{c}\text { Coefficient } \\
\text { (p-value) }\end{array}$ \\
\hline Intercept & $?$ & $\begin{array}{l}-0.633 \\
(0.27)\end{array}$ \\
\hline ROE & + & $\begin{array}{c}0.533 \\
(0.007) \\
\end{array}$ \\
\hline YEARS_TO_RETIRE & + & $\begin{array}{l}0.002 \\
(0.94)\end{array}$ \\
\hline SERVCOST & - & $\begin{array}{c}-10.904 \\
(0.70) \\
\end{array}$ \\
\hline LABINT & - & $\begin{array}{l}-0.339 \\
(0.28) \\
\end{array}$ \\
\hline UNEMP & - & $\begin{array}{c}-0.051 \\
(0.29) \\
\end{array}$ \\
\hline PBO & + & $\begin{array}{c}1.980 \\
(0.001) \\
\end{array}$ \\
\hline FUNDING & + & $\begin{array}{c}0.853 \\
(0.004)\end{array}$ \\
\hline SIZE & + & $\begin{array}{c}0.240 \\
(0.0001) \\
\end{array}$ \\
\hline No. of observations & & 258 \\
\hline Obs. with $\mathrm{CB}=1$ & & 123 \\
\hline Obs. with $\mathrm{CB}=0$ & & 135 \\
\hline
\end{tabular}


Prior research (e.g., Petersen 1992) suggests that incentives to breach the implicit contract with employees increase with the magnitude of the pension bond that employees have invested in the firm. If switches away from traditional DB plans are motivated by the desire to tap into the pension bond investment of employees, the probability of the switch should increase with the relative age of the workforce in the firm. Since we do not have access to data on the age distribution of the employees of individual firms, we use YEARS_TO_RETIRE as a proxy for the average number of future years of service for firms' employees. A negative coefficient on YEARS_TO_RETIRE would support the breach of implicit contract hypothesis. If, on the other hand, the decision to switch away from traditional DB plans is motivated by a desire to retain younger employees, one would expect to see more conversions in firms with a higher proportion of younger employees evidenced by a positive coefficient on YEARS_TO_RETIRE. The coefficient on YEARS_TO_RETIRE in Panel A of Table 5 is significantly negative, providing more evidence consistent with the hypothesis that both CB conversions and terminations of traditional DB plans represent a breach of implicit contract with employees.

Firms with higher pension expenses are likely to have greater incentives to reduce these expenses. If financial considerations are important determinants of the decision to abandon traditional DB plans, firms with higher pension expenses will be more likely to make the switch. We focus on the service cost component, SERVCOST, of pension expense because this component, which is not affected by the investment performance of pension plan assets, is less noisy than the total pension expense. SERVCOST is measured as the ratio of pension service cost to sales revenue and is a proxy for the cost of the pension plan to the firm. The coefficient on SERVCOST is positive and marginally significant (two-tailed $\mathrm{p}$-value $=0.10$ ).

Pension costs are also likely to be more salient for labor intensive firms, where employee-related costs are a larger proportion of total costs, rather than for capital intensive firms. Consistent with the results obtained for SERVCOST, which support cost savings as a motivation for CB conversions, the coefficient on our proxy for labor intensity, LABINT, in Panel A of Table 5 is significantly positive.

If firms move away from traditional DB plans to attract employees in tight labor markets, we would expect to observe more switches in industries with low unemployment. We introduce the variable UNEMP to capture this effect, where UNEMP is the average unemployment rate in the industry in the 1985-2002 period, industry being defined by the two-digit SIC code. The labor market response hypothesis predicts a negative coefficient on this variable. However, if higher industry unemployment rates increase the bargaining power of employers and reduce the costs associated with the breach of implicit contracts, a positive coefficient on UNEMP would be consistent with our earlier results supporting the notion that the switch away from traditional DB plans imposes costs on employees. Panel A of Table 5 shows that the coefficient on UNEMP is positive, but not significant at conventional levels (twotailed $\mathrm{p}$-value $=0.18$ ).

PBO is a measure of the relative size of a firm's pension obligation. Firms with larger pension obligations have more incentive to make changes that reduce those obligations. However, to the extent that PBO proxies for greater expected employee resistance to a break in the terms of their implicit contract, it might act as a deterrent against such breaches. The coefficient on PBO in Panel A of Table 5 is significantly negative, consistent with pension size being a proxy for political costs.

We make no directional predictions for SIZE or FUNDING. If SIZE is a proxy for political costs, we would expect a negative coefficient on this variable. However, SIZE also captures the ability of firms to bear the non-trivial administrative costs of implementing changes such as CB conversions, which would argue for a positive coefficient. Estimation results show that the coefficient on SIZE is insignificantly different from zero. Traditional DB firms with overfunded pension plans have disincentives to terminate their DB plans because of the tax consequences (Niehaus and Yu 2004). However, no such disincentives exist with regard to CB conversions, since CB plans are still technically defined benefit plans, making it difficult to predict the sign on FUNDING overall. Panel A of Table 5 shows that the coefficient on FUNDING is negative and marginally significant. If traditional DB firms with overfunded pension plans are in better financial shape, these results could capture another facet of the impact of financial health on pension plan choices. 
In Panel B of Table 5, we present the results of the estimation of stage 2 of the Heckman selection model, the determinants of the CB conversion vs. DB plan termination choice. Results are broadly consistent with earlier analyses which support the assertion that $\mathrm{CB}$ conversions might represent less severe breaches of the implicit contract with employees. The coefficient on ROE is positive and highly significant. Within the subset of firms that have chosen to abandon the traditional DB plan, more profitable firms are more likely to convert to CB than terminate their DB plan.

Given that both the desire to avoid political costs (Zimmerman, 1983) and the ability to shoulder the higher administrative costs associated with CB conversions would make converting to CB the preferred option for larger firms, we predict a positive coefficient for SIZE. Results support these arguments: the coefficient on SIZE in panel B of Table 5 is positive and highly significant. So is the coefficient on PBO, reinforcing the notion that pension size is a proxy for costs associated with breaching labor contracts.

As argued earlier, firms with overfunded pension plans have incentives to prefer CB conversions to DB plan terminations, if they decide to switch away from the traditional DB format. Firms with overfunded DB pension plans face both income and excise tax penalties on reverted excess plan assets if they terminate DB plans. Since CB conversions are not technically DB plan terminations, firms avoid these adverse tax consequences with the CB conversion option. Moreover, DB plan termination will result in the loss of the financial reporting benefits associated with the potential use of the expected return on plan assets to increase reported income. Consistent with these arguments, Panel B of Table 5 shows that the coefficient on FUNDING is positive and highly significant.

The coefficients on other cost/benefit proxies (YEARS_TO_RETIRE, SERVCOST, LABINT, UNEMP) are all in the predicted direction, but are not statistically significant. Overall, our results indicate that firm profitability, political costs, the anticipation of employee resistance, the desire to retain the financial reporting benefits of DB plans and/or tax considerations explain the choice between CB conversions and plan terminations. ${ }^{27}$ Large, profitable firms and firms with greater pension obligations are more likely to face employee resistance and other forms of political costs, possibly explaining why these firms choose the less costly CB conversion route.

\section{ANALYSIS OF PENSION COST BEHAVIOR AROUND CONVERSION}

Past analyses suggest that $\mathrm{CB}$ conversions are an example of a breach of implicit contract with employees, albeit less severe than DB plan terminations. Our results are consistent with CB conversions being part of a strategy to reduce pension costs and the pension obligation. ${ }^{28}$ In this section, we analyze more directly whether $\mathrm{CB}$ conversions are associated with wealth transfers by studying the behavior of various accounting measures of pension costs and obligations around conversion years. We analyze patterns in the time-series of pension variables for CB firms (pre- and post-conversion) and matched firms that retain their traditional DB plans.

If a company's conversion from a traditional $\mathrm{DB}$ plan to a $\mathrm{CB}$ plan constitutes a negative plan amendment as per SFAS 87, the positive effects of this amendment on financial statements will be recognized as a reduction in prior service costs. To recognize the reduction in the projected benefit obligation due to the amendment, the company first reduces the balance of any existing unrecognized prior service cost. Any excess becomes a negative unrecognized prior service cost.

We first examine changes in unrecognized prior service cost in the years surrounding the conversion. We perform this analysis for the samples of CB and matched firms that retained DB plans over an 11-year period

\footnotetext{
${ }^{27}$ Some of our results differ from those of Kapinos (2009 and 2012). One possible explanation is that we select our control sample of DB firms by matching on firm size and industry and she does not. Although she includes a control variable for firm size in some models, this variable might not control completely for the impact of firm size. Additionally, the multinomial logit models in the Kapinos (2012) study include explanatory variables (age distribution of employees, portion of female employees, and presence of unionized employees) and controls for industry fixed effects, but they do not include any other control variables. Other studies, including Kapinos (2009), document associations between firm size (and other factors) and the likelihood of CB conversion.

${ }^{28}$ These results are consistent with a survey of CB plan sponsors by PricewaterhouseCoopers (2000) indicating that 56 percent of firms expected long-term costs of DB plans to decrease after conversion.
}

2013 The Clute Institute http://www.cluteinstitute.com/ 
surrounding the conversion year (for years -5 through year +5 , with 0 being the conversion year). We scale changes in unrecognized prior service costs between years by the projected benefit obligation in that year. Panel A of Table 6 shows that $\mathrm{CB}$ firms had a more negative change in unrecognized prior service costs than their matched firms in the year of the conversion, although a fraction of this change reverses the following year. Results are consistent with CB conversions reducing the pension obligation. Moreover, since the unrecognized prior service cost is amortized in future years, the effect of $\mathrm{CB}$ conversions is likely to increase future reported income.

Table 6

Pension Variables around Conversion Year Comparison of CB Firms to Firms that Retain Traditional DB Plans

Panel A: Changes in Unrecognized Prior Service Cost

\begin{tabular}{|c|c|c|}
\hline Year relative to conversion year & \multicolumn{2}{|c|}{ Change in Unrecognized Prior Service Cost } \\
\cline { 2 - 3 } & CB firms & Matched DB firms \\
\hline $\mathbf{- 5}$ & 0 & 0 \\
\hline $\mathbf{- 4}$ & 0 & 0 \\
\hline $\mathbf{- 3}$ & -0.001 & 0 \\
\hline $\mathbf{- 2}$ & -0.002 & 0 \\
\hline $\mathbf{- 1}$ & -0.029 & $0.029^{* *}$ \\
\hline $\mathbf{0}$ & $-0.163^{* *}$ & -0.002 \\
\hline $\mathbf{1}$ & $0.049^{* *}$ & 0 \\
\hline $\mathbf{2}$ & 0 & -0.054 \\
\hline $\mathbf{4}$ & 0 & -0.030 \\
\hline $\mathbf{5}$ & 0 & 0.03 \\
\hline
\end{tabular}

Panel B: Projected Benefit Obligation and Pension Service Costs

\begin{tabular}{|c|c|c|c|c|}
\hline $\begin{array}{c}\text { Year relative to } \\
\text { conversion year }\end{array}$ & \multicolumn{2}{|c|}{ Projected Benefit Obligation } & \multicolumn{2}{c|}{ Pension Service Cost } \\
\hline & CB firms & Matched DB firms & CB firms & Matched DB firms \\
\hline $\mathbf{- 5}$ & 67.8 & 69.0 & 77.5 & 82.5 \\
\hline $\mathbf{- 4}$ & 76.0 & 73.4 & 87.5 & 85.5 \\
\hline $\mathbf{- 3}$ & 84.6 & 82.6 & 87.2 & 89.0 \\
\hline $\mathbf{- 2}$ & 93.2 & 90.6 & 95.6 & 95.1 \\
\hline $\mathbf{- 1}$ & 100.0 & 100.0 & 100.0 & 100.0 \\
\hline $\mathbf{0}$ & $103.9^{*}$ & $108.8^{*}$ & 104.1 & 106.3 \\
\hline $\mathbf{1}$ & 108.0 & 113.9 & 102.3 & 109.7 \\
\hline $\mathbf{2}$ & $115.5^{* *}$ & $124.1^{* *}$ & 102.7 & 108.1 \\
\hline $\mathbf{4}$ & $128.8^{*}$ & $136.7^{*}$ & 113.3 & 115.8 \\
\hline $\mathbf{5}$ & $127.6^{* *}$ & $141.4^{* *}$ & 114.9 & 123.0 \\
\hline
\end{tabular}

Notes: Differences between samples are tested for using the Wilcoxon signed rank test. In Panel A, changes in unrecognized prior service cost are expressed as a percentage of the projected benefit obligation for the firm. In Panel B, projected benefit obligation and pension service costs are expressed on a per employee basis and as a percentage of their values in the year prior to the conversion to $\mathrm{CB}$ plans.

***,*** $\quad$ Differences between the samples are significant at the $1 \%$ level, $5 \%$ level, and $10 \%$ level, respectively.

We also investigate the pattern, around the conversion year, in the projected benefit obligation and pension service costs for both the CB and the matched DB firms, and report results in panel B of Table 6. Both the pension obligation and service costs for each firm are expressed on a per employee basis, scaled by their values in the year prior to $\mathrm{CB}$ conversion and reported as a percentage of this value. We see that the projected benefit obligation of $\mathrm{CB}$ firms is close to that of the matched firms until the year of $\mathrm{CB}$ conversion. In every year, from that point forward, it grows more slowly for CB firms than for matched firms. The difference between samples is significant at the $10 \%$ level or better in every year following the change except in year 2. CB conversions appear to rein in the growth of the pension obligation. 
The results for service costs are similar. Service costs for CB firms are higher than those of matched firms prior to $\mathrm{CB}$ conversion and lower every year after the conversion, becoming significantly lower by post-conversion year 5. On average, therefore, $\mathrm{CB}$ conversions reduce both the pension obligation and pension service costs.

\section{SENSITIVITY TESTS}

As a sensitivity measure, we also run two different sets of logistic estimations, comparing CB converters to i) firms that retain traditional DB plans; and ii) DB plan terminators. As an alternative control for industry effects, we use a matched pair design, matching CB firms with firms in the same industry within each control sample. Results, not reported in the interests of brevity, are qualitatively similar to the results of univariate analyses, and similar in spirit to those reported for the Heckman selection model.

We also examine whether firms undertaking CB conversions have a history of good or poor employee relations. We construct a measure of employee relations (EMPREL) as a composite of ratings of different facets of employee relations compiled by KLD Research \& Analytics Inc. These facets include union relations, layoff and workforce reduction records, profit-sharing policies, employee involvement in management and quality of retirement benefits. We find this variable is not statistically significant in our logit models. ${ }^{29}$

Research on pension plan terminations and reversions (e.g., Ippolito, 1986; Stone, 1987; Thomas, 1989; Mittelstaedt, 1989) finds that financing and cash flow considerations are the primary motivations for these actions. Unlike pension reversions, CB conversions are not an immediate source of financing and cash flow. Nevertheless, we examine the role of financing and cash flow considerations in CB conversions. We introduce cash flow variables (cash flow from operations, cash flow from investing) and variables that proxy for the ease with which firms can undertake additional borrowing (debt to assets ratio, ratio of fixed to total assets, ratio of intangible to total assets) in the logistic regression. Consistent with Harper and Treanor (2011), our results indicate that CB conversions are not driven by a need for immediate cash flow and do not substitute for borrowing in financing the firm.

Firms could have converted to $\mathrm{CB}$ plans to obtain relief from limits on the tax deductibility of pension funding imposed by the Omnibus Budget Reconciliation Act of 1987 (OBRA'87). ${ }^{30}$ Prior to OBRA'87, contributions to pension plans were tax deductible up to the full funding limit (corresponding to the projected benefit obligation, $\mathrm{PBO}$ ). OBRA' 87 limited tax deductibility to $150 \%$ of the ABO. Converting to CB plans could alleviate this constraint for some firms. We introduce an indicator variable in the logistic regression that takes the value one for all firms where the $\mathrm{PBO}$ is greater than $150 \%$ of the $\mathrm{ABO}$ in the year prior to conversion. The coefficient on this indicator variable is not statistically significant at conventional levels in our models. Our results, therefore, do not indicate that OBRA' 87 is a major driver of the conversion decision.

Media reports and Congressional hearings testimony have questioned the role of larger benefits consulting and actuarial firms in promoting CB conversions, suggesting that these firms have a vested interest in increasing consulting revenue. To investigate whether being a client of one of the larger actuarial firms is related to the conversion decision, we introduced an indicator variable ACTUARY in the model. ACTUARY took the value 1 if the firm is a client of one of the eight largest actuarial firms (in terms of number of plans served in 1998), and zero otherwise. This variable is not significant in our analyses.

\footnotetext{
${ }^{29}$ We also examine whether use of incentive compensation is a factor in CB conversions. We measure incentive compensation as natural logarithm of the ratio of incentive compensation to salary for the CEO of the firm for the year. Univariate test results reveal no significant differences in incentive compensation between either: (1) CB firms and DB firms or (2) CB firms and terminators. However, time series tests reveal CB firms use more incentive compensation than DB firms in years prior to the conversion, which supports accusations in the business press (for example, see Pensions and Investments, June 12, 2000, p.12) that CEOs with more incentive compensation are more likely to reduce pension costs in order to boost earnings, elevate the firm's stock price and increase their personal wealth.

${ }^{30}$ See 'Unfolding of a predictable surprise' by Watson Wyatt Worldwide.
}

2013 The Clute Institute http://www.cluteinstitute.com/ 


\section{SUMMARY AND CONCLUSIONS}

Proponents of CB plans assert that employees in today's more mobile workforce benefit from CB plans because they are more portable than traditional DB plans. Critics, however, suggest that the conversions are primarily motivated by cost savings, achieved at the expense of older workers with longer tenure. This study provides evidence on the relative merit of these possible explanations.

We find that $\mathrm{CB}$ conversions are not associated with proxies for greater labor mobility (e.g., employee turnover or industry unemployment rate). They are associated with a workforce that is closer to retirement, on average, lending credence to breach of implicit contract rather than labor market response as a motivator of $\mathrm{CB}$ conversions. ${ }^{31}$ We also find CB converters have lower profitability and higher pension service costs prior to the change. However, pension costs and obligations grow more slowly after the conversion among CB firms than those retaining traditional $\mathrm{DB}$ plans. These results are consistent with $\mathrm{CB}$ conversions as attempts to rein in pension costs to improve profitability.

Pension costs could be controlled at least as well by DB plan terminations, followed by the institution of DC plans, as frequently witnessed in the 1980s. Niehaus and Yu (2004) argue that the increase in excise taxes on reversion of excess pension plan assets made pension plan terminations less desirable after 1990. We offer, and find some evidence in favor of, a competing explanation for the increased popularity of CB conversions in more recent years: CB conversions offer firms with DB plans the opportunity to retain the financial reporting benefits of the DB classification (likely to be particularly attractive in periods such as the late 1990s when stock market valuations were high) while reining in pension costs and obligations. We add the caveat that financial exigency, cost reduction and political costs might be the primary considerations, with financial reporting benefits a secondary factor in the decision between converting and terminating.

Overall our results suggest that firms for whom pension terminations are costly in terms of employee resistance, political visibility or explicit tax costs and those that are more likely to have financial accounting benefits from retaining DB status are more likely to convert to $\mathrm{CB}$ plans than terminate their plans. We do not find evidence supporting claims that $\mathrm{CB}$ conversions are a response to tighter labor markets and a more mobile workforce. Overall, while we cannot conclusively rule out the labor markets hypothesis, we do find substantive evidence consistent with the breach of implicit contract hypothesis.

This study has some limitations. Because data on the age profile of firms' employees are not publicly available, we must rely on estimates using data from pension footnotes. One of our measures of within-industry labor market conditions is the average industry unemployment rate, which may not capture individual firm nuances. Finally, our analysis groups all CB conversions into a single category. Differences in the terms of CB plans and in transition provisions could introduce noise into the analysis. Despite these shortcomings, we believe that our paper makes a significant contribution and is the most comprehensive examination of the cash balance controversy to date.

\section{ACKNOWLEDGEMENTS}

We thank Michael Eames, Dov Fischer, S. P. Kothari, Greg Niehaus, Srini Rangan, Steve Rock, Brendan O'Connell, and seminar participants at North Carolina State University for their helpful comments.

\section{AUTHOR INFORMATION}

Julia D'Souza, Ph.D., Johnson Graduate School of Management, Cornell University, Ithaca, NY 14853 USA. E-mail: jd48@cornell.edu

John Jacob' Ph.D., Leeds School of Business, University of Colorado at Boulder, Boulder Colorado USA. Posthumous

\footnotetext{
${ }^{31}$ We do not take a normative stand on the breach of implicit contract issue. 
Barbara Lougee, Ph.D., School of Business Administration, University of San Diego, 5998 Alcala Park, San Diego, CA 92110 USA. E-mail: blougee@ sandiego.edu (Corresponding author)

\section{REFERENCES}

1. Cheng, Q. and Warfield, T. (2006). Equity Incentives and Earnings Management, The Accounting Review 80 (2), 441-476.

2. Coronado, J.L. and Copeland, P.C. (2004). Cash balance pension plan conversions and the new economy, Journal of Pension Economics and Finance, 297-314.

3. Cowan, A.R. and Power, M.L. (2003). Determinants of corporate conversions to CB pension plans, working paper, Iowa State University.

4. Erickson, M., Hanlon, M. and Maydew, E.L. (2004). How much will firms pay for earnings that do not exist? Evidence of taxes on allegedly fraudulent earnings, The Accounting Review, 79(2), 387-408.

5. Financial Accounting Standards Board, (1985). Statement of Financial Accounting Standards No. 87, Employers' Accounting for Pensions.

6. Harper, J. and Treanor, S. (2011). Pension Conversion, Termination, and Wealth Transfers, working paper, Oklahoma State University.

7. Haw, I., Jung, K. and Lilien, S. (1991). Overfunded DC pension plan settlements without asset reversions, Journal of Accounting and Economics, 14, 295-320.

8. Ippolito, R. (1985). The labor contract and true economic pension liabilities, American Economic Review 75, 1031-1043.

9. _ R. (1986). Pensions, Economics, and Public Policy, Chapter 13: Termination for Reversions (Dow Jones-Irwin: Homewood, IL).

10. Kapinos, K. (2009). On the Determinants of Defined Benefit Pension Plan Conversions, Journal of Labor Research 30: 149-167.

11. _ K. (2012). Changes in Firm Pension Policy: Trends Away from Traditional Defined Benefit Plans, Journal of Labor Research 33: 91-103.

12. Mittelstaedt, H.F. (1989). An empirical analysis of the factors underlying the decision to remove excess assets from overfunded pension plans. Journal of Accounting and Economics 11: 399-418.

13. Niehaus, G. and Yu, T. (2004). Cash balance plan conversions: evidence on excise taxes and implicit contracts, Journal of Risk and Insurance, 321-352.

14. Petersen, M. A. (1992). Pension reversions and worker-stockholder wealth transfers, Quarterly Journal of Economics 52, 1033-1056.

15. Roychowdhury, S. (2006). Management of earnings through real activities manipulation, Journal of Accounting and Economics, 42:3 335-370.

16. Stone, M. (1987). A financing explanation for overfunded pension plan terminations, Journal of Accounting Research 25, 317-326.

17. Subramanyam, K. R. and Zhang, Y. (2000). Does stock price reflect future service effects not included in the projected benefit obligation as defined in SFAS 87 and SFAS 132?, working paper, University of Southern California.

18. Thomas, J. K. (1989). Why do firms terminate their overfunded pension plans? Journal of Accounting and Economics 11, 361-98.

19. United States Department of Labor, (2012). Private Pension Plan Bulletin Historical Tables and Graphs. Employee Benefits Security Administration, Washington, DC.

20. _ (2011). Private Pension Plan Bulletin, Abstract of 2009 Form 5500 Annual Reports. Employee Benefits Security Administration, Washington, DC.

21. United States Department of Labor and United States Bureau of Labor Statistics, (2012). National Compensation Survey: Employee Benefits in the United States. Bulletin 2773. Washington, DC.

22. United States Government Accountability Office, 2005, Private Pensions: Information on Cash Balance Pension Plans. GAO-06-42. Washington, DC.

23. (2000). Cash Balance Plans: Implications for Retirement Income. GAO/HEHS-00-207. Washington, DC.

24. (2000). Private Pensions: Implications of Conversions to Cash Balance Plans. GAO/HEHS-00185.

2013 The Clute Institute http://www.cluteinstitute.com/ 
25. Van De Ven, W.P.M.M. and Van Praag, B.M.S. (1981) The Demand for Deductibles in Private Health Insurance: A Probit Model with Sample Selection, Journal of Econometrics 17, 229-252.

26. Watson Wyatt Worldwide, (2000). The unfolding of a predictable surprise: A comprehensive analysis of the shift from traditional pensions to hybrid plans.

27. Zimmerman, J. L. (1983). Taxes and firm size, Journal of Accounting and Economics 5, 119-149, 1983. 